\title{
Implementasi Edukasi Kesehatan HIV Dalam Perubahan Stigma HIVIAIDS Pada Mahasiswa Keperawatan
}

\author{
Angga Wilandika \\ Sekolah Tinggi IImu Kesehatan 'Aisyiyah Bandung \\ E-mail: wiland.angga@gmail.com
}

\begin{abstract}
ABSTRAK
Stigma dan diskriminasi terhadap orang dengan HIVIAIDS (ODHA) yang dilakukan perawat menyebabkan hambatan pada pelayanan asuhan keperawatan. Kejadian stigma tidak lepas kaitannya dengan persepsi stigma ketika mereka masih menjadi mahasiswa atau calon perawat. Stigma pada mahasiswa ini muncul dan berkembang karena pengetahuan mengenai HIV yang dimilikinya tidak komprehensif. Salah satu upaya untuk mengatasi hal ini dilakukan melalui penguatan informasi melalui program edukasi kesehatan HIV. Pelaksanaan edukasi kesehatan HIV ini dilakukan secara secara daring kepada 40 orang mahasiswa keperawatan. Setelah dilaksanakan kegiatan edukasi kesehatan HIV, menunjukkan sebagian besar mahasiswa $(72,5 \%)$ memiliki tingkat pengetahuan HIV berkategori baik. Selain itu, mahasiswa yang memiliki stigma (negatif) terhadap ODHA menurun menjadi 52,5\%, yang awalnya sebesar $77,5 \%$. Walaupun edukasi kesehatan ini belum mampu secara utuh menghilangkan stigma, tetapi perubahan pandangan stigma ini menjadi suatu upaya dalam eradikasi stigma pada ODHA. Rekomendasi dari kegiatan ini yaitu perlu dikembangkan strategi yang lebih komprehensif dan lebih mendalam untuk perubahan stigma pada mahasiswa keperawatan.
\end{abstract}

Kata kunci : Edukasi, HIVIAIDS, mahasiswa keperawatan, ODHA, stigma

\begin{abstract}
Stigma and discrimination against people living with HIVIAIDS (PLWHA) by nurses causes obstacle to nursing care services. The incidence of stigma cannot be separated from the perception of stigma when they were students or prospective nurses. The stigma in these students emerged because their knowledge of HIV was not comprehensive. One of the efforts to overcome this is through strengthening information through HIV health education programs. The implementation of HIV health education was carried out online to 40 nursing students. After carrying out HIV health education, it showed that most students (72.5\%) had a good level of knowledge about HIV. In addition, students who have a (negative) stigma against PLWHA decreased to $52.5 \%$, which was initially $77.5 \%$. Although health education has not been able to completely eliminate stigma, this change in stigma views has become an effort to eradicate stigma among PLWHA. The recommendation of this activity were that a more comprehensive strategy should be developed to eliminate stigma among nursing students towars PLWHA.
\end{abstract}

Keywords: Education, HIVIAIDS, nursing students, PLWHA, stigma

\section{PENDAHULUAN}

Gaung "Indonesia Bebas Stigma" pada kelompok penyandang HIVIAIDS merupakan cita-cita yang ingin diwujudkan oleh Indonesia. Walaupun, sampai saat ini permasalahan stigma HIV di Indonesia masih tinggi dan belum terselesaikan. Selain dari masyarakat, stigma terhadap orang dengan HIVIAIDS (ODHA) berasal dari kalangan petugas kesehatan. Petugas kesehatan yang salah satunya perawat merupakan orang paling dekat dengan pasien. Sehingga apabila stigma yang merupakan pandangan negatif muncul dari dalam diri perawat maka akan memunculkan tindakan diskriminasi.

Stigma dan diskriminasi terhadap ODHA yang dilakukan oleh perawat dapat berdampak kepada pelayanan asuhan keperawatan yang tidak optimal. Hasil studi Hoffart et.al (2012) menemukan bahwa tenaga kesehatan yang memiliki pandangan negatif terhadap pasien dengan HIV positif mengalami perubahan sikap profesional dalam merawat pasien ke arah yang kurang baik. Penurunan pelayanan dalam memberikan asuhan kepada pasien dengan HIV ini menyebabkan permasalahan infeksi HIV dan gejala-gejala yang 
ditimbulkannya akan lebih sulit untuk ditangani. Terlebih lagi, stigma yang muncul dari petugas kesehatan seperti perawat juga akan berkontribusi terhadap hilangnya kesempatan dalam pencegahan penularan HIV, dan bahkan mempersulit pengendalian infeksi HIV (Vorasane et al., 2017)

Selain itu, berdasarkan hasil penelitian penulis mengenai penilaian stigma petugas kesehatan pada ODHA, menemukan juga bahwa kejadian stigma pada kalangan petugas kesehatan yang sudah bekerja di salah satu Puskesmas di Bandung tergolong cukup tinggi. Sebagian besar petugas kesehatan (60\%) yang salah satunya adalah perawat masih mempunyai stigma negatif yang kuat kepada pasien HIV atau orang ODHA yang berkunjung ke fasilitas kesehatan tersebut (Wilandika, 2019). Kejadian stigma pada perawat ini akan mempersulit proses penanganan pasien yang berobat karena penyakit HIVIAIDS (Machowska et al., 2020) dan menghambat upaya penanggulangan HIV di Indonesia.

Stigma terhadap ODHA yang muncul pada perawat bersumber dari kurang lengkapnya pengetahuan yang dimiliki perawat mengenai permasalahan dan penularan infeksi HIV. Kejadian diskriminasi pada pasien HIV yang dilakukan oleh terjadi akibat ketidaktahuan perawat mengenai tata laksana perawatan pasien HIV termasuk mengenai pencegahan penularan infeksi HIV (Vorasane et al., 2017; Machowska et al., 2020). Oleh karena itu, penguasaan pengetahuan mengenai penularan infeksi HIV dan penatalaksanaan penanganan pasien dengan HIVIAIDS harus dimiliki secara utuh oleh seorang perawat.

Pemberian informasi mengenai penyakit HIV pada seorang perawat bermula dari bangku pendidikan, ketika masih berstatus sebagai mahasiswa. Pendidikan formal yang dijalani oleh seorang mahasiswa menjadi jalan masuk untuk memahami berbagai kondisi dan gejala yang muncul dari penyakit HIV. Walaupun demikian, ada kalanya informasi yang diberikan tentang suatu kondisi penyakit mengalami kendala dalam hal pendalaman suatu penyakit ketika pembelajaran di dalam kelas. Baik kendala dalam hal waktu pembelajaran yang terbatasi oleh jam sks mata kuliah ataupun kondisi mahasiswa yang beragam pada saat pembelajaran.

Selain itu juga, ragam penyakit yang banyak muncul di masyarakat yang harus dipahami dan dikuasai oleh mahasiswa juga menjadi tantangan dalam memahami dan menguasai permasalahan tersebut. Terlebih lagi jika merujuk kepada kurikulum yang berlaku di institusi pendidikan maupun kurikulum nasional, informasi HIV yang wajib diberikan kepada mahasiswa, tidak memfasilitasi pendalaman permasalahan HIV, khususnya mengenai penghapusan stigma pada mahasiswa.

Oleh karena itu diperlukan suatu strategi edukasi yang tepat dalam memahami kondisi penyakit HIVIAIDS sehingga pada akhirnya setiap mahasiswa yang nantinya akan bekerja di lapangan memahami terkait penyakit HIV dan tidak memunculkan stigma ataupun diskriminasi kepada pasien dengan HIVIAIDS. Tujuan dari pengabdian kepada masyarakat ini yaitu merubah stigma mahasiswa terhadap ODHA melalui edukasi kesehatan dengan cara peningkatan pengetahuan mengenai HIVIAIDS.

\section{BAHAN DAN METODE}

Kegiatan pengabdian kepada masyarakat melaui edukasi kesehatan ini dilakukan secara daring atau berbasis online. Khalayak sasaran yang dipilih dalam kegiatan ini yaitu mahasiswa keperawatan yang berasal dari salah satu perguruan tinggi kesehatan swasta di Bandung. Sebanyak 40 orang dilibatkan dalam kegiatan ini. Edukasi kesehatan ini dilaksanakan selama 1 (satu) pertemuan yaitu pada tanggal 4 Juni 2020, dengan materi yang diberikan selama 4 jam pembelajaran.

Sebelum pelaksanaan edukasi kesehatan, peserta diminta mengisi kuesioner untuk mengukur tingkat pengetahuan dan stigma (pra-tes). Kemudian pada akhir pertemuan, peserta mengisi kembali kuesioner tersebut (pasca-tes). Pelaksanaan pra-tes dan pasca-tes dilakukan menggunakan formulir online. Instrumen yang digunakan untuk menilai pengetahuan HIVIAIDS yaitu Kuesioner Pengetahuan HIVIAIDS yang dikembangkan oleh 
Wilandika (2017). Sementara itu, untuk mengukur stigma terhadap ODHA digunakan Kuesioner Penilaian Stigma HIVIAIDS Petugas Kesehatan dari Wilandika (2019) yang merupakan modifikasi Kuesioner Health Care Provider HIVIAIDS Stigma Scale (HPASS) (Wagner et al., 2014).

\section{HASIL}

Hasil yang diperoleh dari kegiatan edukasi kesehatan ini yaitu peserta kegiatan yang terlibat adalah mahasiswa yang seluruhnya (100\%) muslim atau beragama Islam. Rentang umur mahasiswa berkisar antara 18 - 21 tahun. Peserta kegiatan sebagian besar $(80,09 \%)$ adalah mahasiswa dengan jenis kelamin perempuan dan seluruhnya (100\%) belum menikah.

Berdasarkan pengukuran terhadap tingkat pengetahuan HIV pada 40 orang mahasiswa tersebut ditemukan bahwa sebelum pelaksanaan edukasi kesehatan, hampir setengahnya $(47,5 \%)$ mahasiswa memiliki tingkat pengetahuan HIVIAIDS berkategori baik. Namun, setelah edukasi kesehatan, sebagaian besar $(72,5 \%)$ mahasiswa memiliki tingkat pengetahuan HIVIAIDS berkategori baik. Hal ini menunjukkan adanya peningkatan pengetahuan tentang HIVIAIDS pada mahasiswa sebesar $25,0 \%$.

Sementara itu, penilaian stigma terhadap ODHA juga mengalami perubahan. Di mana pada saat awal pengukuran, sebelum pelaksanaan edukasi kesehatan, sebagian besar $(77,5 \%)$ mahasiswa memiliki stigma (negatif) yang tinggi terhadap ODHA. Akan tetapi, setelah dilakukan edukasi kesehatan, stigma (negatif) mahasiswa menurun menjadi 52,5\%. Dengan demikian, terlihat bahwa stigma mahasiswa terhadap ODHA yang berkategori rendah mengalami mengalami peningkatan sebesar $25,0 \%$ setelah dilakukan pendampingan kesehatan. Walaupun jika dilihat secara keseluruhan, sebagin besar stigma mahasiswa terhadap ODHA ini masih cukup tinggi.

\section{PEMBAHASAN}

Stigma sendiri menurut Weiss, et.al (2006) yaitu suatu proses sosial yang dialami oleh seseorang atau sekelompok orang dengan adanya pengucilan, penolakan, menyalahkan atau devaluasi didasarkan pada suatu identitas tertentu yang dianggap berbeda pada umumnya. Stigma yang muncul ini dapat berbentuk penilaian sosial berdasarkan suatu kondisi yang dinilai berbeda dapat berkaitan dengan kesehatan atau identitas lainnya (ras, etnis, preferensi seksual) yang mempengaruhi kesehatan. Eliminasi stigma merupakan kunci utama dalam mengendalikan epidemi HIV dan menyediakan kualitas perawatan yang baik bagi ODHA (Machowska et al., 2020).

Stigma dan diskriminasi terhadap ODHA merupakan permasalahan yang menjadi beban dalam penanganan pengentasan infeksi HIVIAIDS. Apalagi, jika stigma atau diskriminasi tersebut berasal dari perawat, maka akan mempengaruhi kualitas pelayanan kesehatan bagi pasien dengan HIVIAIDS. Seperti yang diungkapkan oleh Wilandika (2019) bahwa stigma yang ditujukan kepada ODHA dari petugas kesehatan atau perawat dapat menimbulkan dampak negatif dan menggangu proses pemberian pelayanan kesehatan atau keperawatan.

Oleh karena itu suatu upaya dini sangat diperlukan dalam mereduksi stigma ini pada petugas kesehatan, terutama pada perawat. Upaya dini dalam menghilangkan stigma ini dapat dimulai dari penguatan-penguatan edukasi sejak bangku pendidikan, yaitu sejak caloncalon perawat masih berada diperguruan tinggi. Salah satu upaya yang dilakukan ada pemberian edukasi untuk mengenal dan memahami apa itu stigma dan diskriminasi pada ODHA serta strategi-strategi dalam mengentaskan stigma yang muncul dikalangan caloncalon perawat. Sehingga pada saatnya mereka harus bekerja di rumah sakit, tidak ada lagi stigma yang muncul dari perawat ditujukan kepada pasien-pasien dengan HIVIAIDS. Dengan demikian, kualitas asuhan keperawatan pasien tetap akan terjaga dan bermutu. Seperti yang diungkapkan oleh Vorasane et al. (2017) bahwa memadukan pengetahuan HIV ke dalam pelatihan atau pendidikan perawat sebelum masa kerja dapat membantu dalam mengatasi 
stigma. Dimana pelatihan yang dimaksud mencakup pengetahuan tentang penularan HIV dan penerapan kewaspadaan universal.

Upaya yang dimaksud di atas adalah strategi penguatan pengetahuan melalui edukasi kesehatan. Edukasi kesehatan dapat dilakukan secara langsung maupun menggunakan media online atau daring (dalam jaringan). Pada kegaitan pendampingan kesehatan ini pemberian edukasi mengenai HIV dan strategi untuk mereduksi persepsi-persepsi stigma pada mahasiswa keperawatan dilakukan menggunakan media virtual atau video conference secara daring.

Implementasi edukasi kesehatan HIV secara daring ini dilaksanakan juga dengan mempertimbangkan kemudahan akses dalam pemberian pendampingan. Sementara itu, keberhasilan edukasi kesehatan secara daring ini terlihat dari perubahan tingkat pengetahuan dan stigma mahasiswa keperawatan terhadap orang dengan HIVIAIDS, dimana tingkat pengetahuan HIV mahasiswa keperawatan mengenai HIV mengalami peningkatan yang signifikan.

Pengetahuan tentang HIV yang meningkat pada mahasiswa keperawatan ini akan berdampak terhadap persepsi stigma negatif yang dimilikinya. Hal ini terlihat dari hasil pengukuran stigma mahasiswa pada ODHA setelah dilakukan edukasi kesehatan HIV secara daring. Mahasiswa dengan stigma (negatif) yang tinggi terhadap ODHA mengalami penurunan yang cukup signifikan. Walaupun secara umum, stigma pada kalangan mahasiswa keperawatan ini sebagian besar masih tergolong tinggi.

Stigma memang bukan sesuatu hal yang dapat dengan mudah dirubah dalam waktu yang singkat. Dalam merubah stigma seseorang diperlukan upaya dan strategi edukasi yang berkelanjutan dan terus menerus. Stigma merupakan persepsi seseorang, sehingga untuk merubah persepsi perlu latihan yang kuat dan lama agar dapat berubah sesuai dengan yang diharapkan.

\section{KESIMPULAN DAN SARAN}

Hasil evaluasi pengabdian kepada masyarakat mengenai edukasi kesehatan HIV secara daring dalam perubahan pengetahuan dan stigma mahasiswa keperawatan terhadap ODHA menemukan adanya perubahan ke arah yang lebih baik. Dimana terdapat perubahan stigma yang terjadi pada kelompok sasaran. Dengan demikian, berdasarkan hasil pelaksanaan pengabdian pada masyarakat ini, dapat disimpulkan bahwa metode edukasi kesehatan HIV secara daring mampu meningkatkan pengetahuan HIV, namun belum maksimal dapat merubah stigma negatif pada mahasiswa keperawatan. Dengan demikian, diperlukan strategi yang lebih komprehensif dan lebih mendalam untuk perubahan stigma pada mahasiswa keperawatan. Stigma memang sesuatu hal yang sulit untuk dirubah dalam pertemuan yang singkat. Perlu dikembangkan kembali metode reduksi stigma yang lebih komprehensif.

\section{UCAPAN TERIMA KASIH}

Ucapan terima kasih penulis sampaikan kepada seluruh pihak yang terlibat serta kepada pihak Sekolah Tinggi IImu Kesehatan 'Aisyiyah Bandung yang telah memberikan dana sehingga kegiatan edukasi ini dapat dilaksanakan dengan baik.

\section{DAFTAR PUSTAKA}

Hoffart, S. et al. (2012) 'Medical students' attitudes towards treating patients with HIV: a 12year follow-up study', Medical teacher. Taylor \& Francis, 34(3), p. 254.

Machowska, A. et al. (2020) "Impact of "HIV-related stigma-reduction workshops" on knowledge and attitude of healthcare providers and students in Central India: a pretest and post-test intervention study', BMJ open. British Medical Journal Publishing Group, 10(4), p. e033612.

Vorasane, S. et al. (2017) 'An investigation of stigmatizing attitudes towards people living 
with HIVIAIDS by doctors and nurses in Vientiane, Lao PDR', BMC health services research. Springer, 17(1), p. 125.

Wagner, A. C. et al. (2014) 'Health care provider attitudes and beliefs about people living with HIV: Initial validation of the health care provider HIVIAIDS Stigma Scale (HPASS)', AIDS and Behavior. Springer, 18(12), pp. 2397-2408.

Weiss, M. G., Ramakrishna, J. and Somma, D. (2006) 'Health-related stigma: rethinking concepts and interventions', Psychology, health \& medicine. Taylor \& Francis, 11(3), pp. 277-287.

Wilandika, A. (2017) 'Pengaruh Case-Based Learning Terhadap Pengetahuan HIVIAIDS, Stigma Dan Penerimaan Mahasiswa Keperawatan Pada ODHA', Jurnal Pendidikan Keperawatan Indonesia, 3(1), pp. 1-12.

Wilandika, A. (2019) 'Health Care Provider Stigma on People Living with HIVIAIDS (PLWHA) in Bandung', Jurnal Keperawatan, 10(1), pp. 7-15. 


\section{LAMPIRAN}

Tabel 1. Karakteristik Mahasiswa yang Terlibat dalam Kegiatan $(n=40)$

\begin{tabular}{lcc}
\hline \multicolumn{1}{c}{ Karakteristik Mahasiswa } & $\mathbf{f}$ & $\%$ \\
\hline Usia & & \\
$\quad$ Rerata umur 19,65 tahun & & \\
$\quad$ Rentang umur 18-21 tahun & & \\
Jenis Kelamin & 8 & 20,0 \\
$\quad$ Laki-laki & 32 & 80,0 \\
$\quad$ Perempuan & & \\
Agama & 40 & 100 \\
$\quad$ Islam & 0 & 0 \\
$\quad$ Non-Islam & & \\
Status Marital & 40 & 100 \\
$\quad$ Belum menikah & 0 & 0 \\
$\quad$ Menikah & & \\
\hline
\end{tabular}

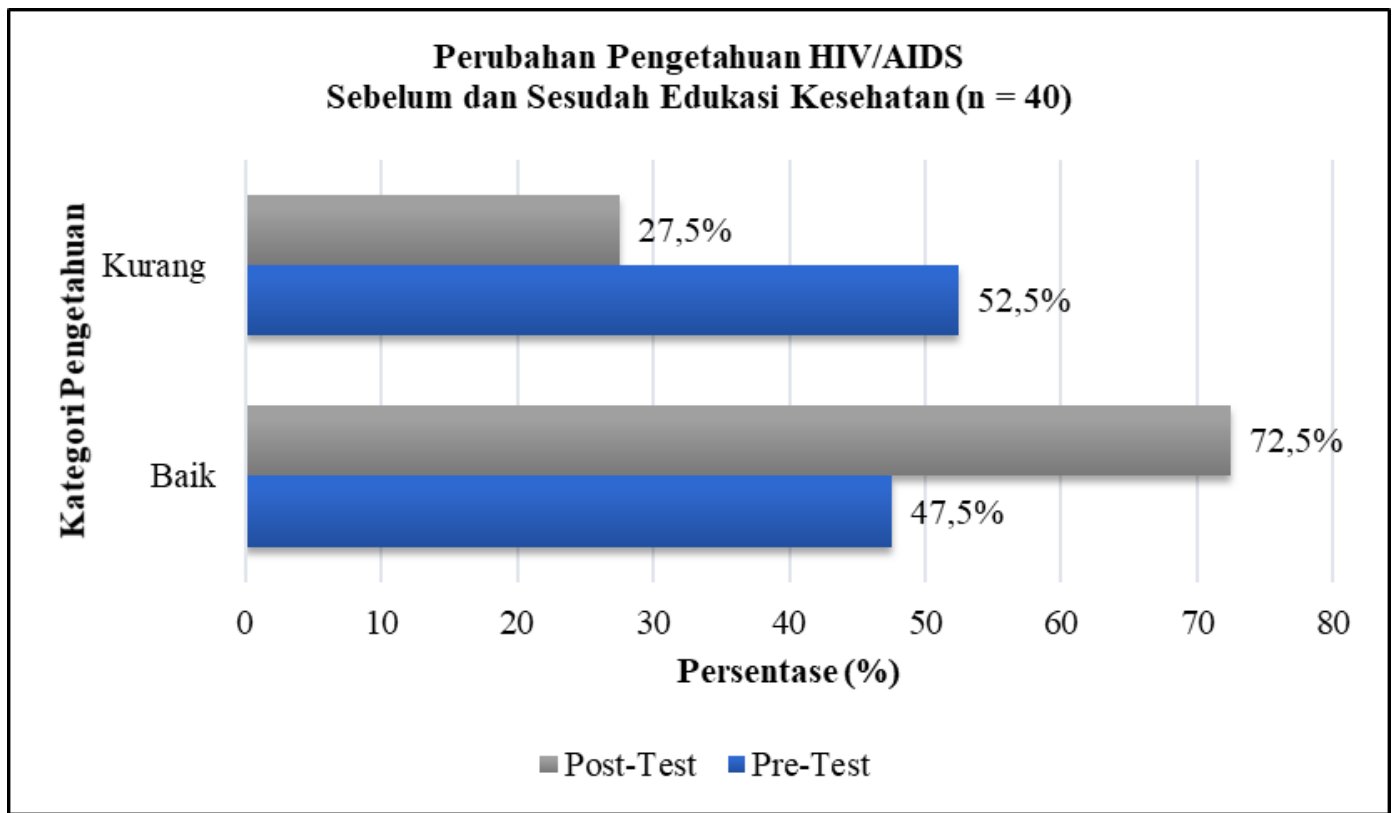

Gambar 1. Tingkat Pengetahuan Mahasiswa tentang HIVIAIDS Sebelum dan Sesudah Edukasi Kesehatan 


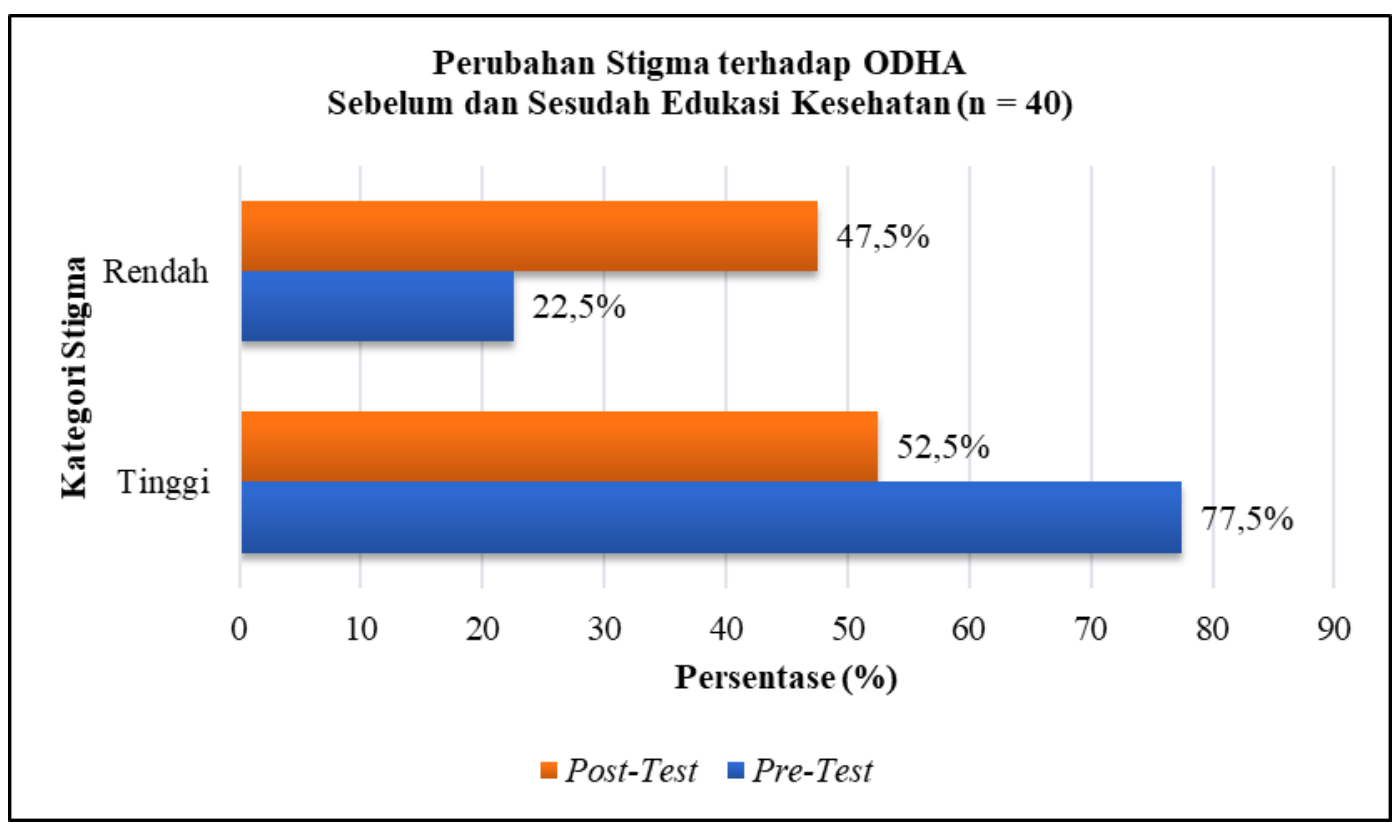

Gambar 2. Stigma Mahasiswa Terhadap ODHA

Sebelum dan Sesudah Edukasi Kesehatan 